\title{
Dimensions of Customer-Based Brand Equity: A Study on Malaysian Brands
}

\author{
Goi Chai Lee and Fayrene Chieng Yew Leh
}

Curtin University, Miri, Malaysia

\begin{abstract}
Although Malaysian market is deluged with value-for-money Malaysian brands since decades ago, not all the Malaysian brand achieved national recognition. The objective of this research is to develop a valid and reliable model of Malaysian brand equity by assessing the dimensions of the brand equity and its constructs. Based on 30 constructs, which were compiled from literatures, four variables were included for brand awareness, seventeen variables for brand association, five for perceived quality and four for brand loyalty. Factor Analysis was conducted to identify dimensions of brand equity and its constructs. Principal Component Analysis with subsequent rotation (varimax) was conducted on 30 constructs of a questionnaire. According to the four dimensions proposed by Aaker (1991) in the brand equity literature, a four factor solution that reduced the 30 constructs to four factors was chosen in this study. The factors produce a Cronbach alpha of 0.96 , with eigenvalues greater than 1.0. The brand equity constructs with a loading below 0.6 were excluded from further analysis. 14 constructs remained in this study.
\end{abstract}

Keywords: Brand Awareness, Brand Associations, Perceived Quality, Brand Loyalty

\section{Introduction}

Malaysian market is deluged with value-formoney Malaysian products in the past decades. However, not all Malaysian consumers recall a Malaysian brand when asked. Most of the Malaysian brands have not yet achieved national recognition. When given a choice of different brands, Malaysian consumers would often choose an international brand over Malaysian brand. However, there are a few Malaysian brands such as Proton, Perodua, MAS, the Shangri-La Hotel chain that had accomplished some measure of success in global stage (Sya, 2004). Building strong brands has been becoming a marketing priority for Malaysian brands.

In today's competitive business environment, the concept of brand equity is an important source of strategic intelligence for marketers. High brand equity levels are known to affect consumer preferences and purchase intentions (Cobb-Walgren et al., 1995), profits and share returns (Srivastava and Shocker, 1991; Aaker and Jacobson, 1994), market power (Farquhar, 1989; Wood, 2000) and sustainable competitive advantages (Bharadwaj et al., 1993), brand extension (Keller and Aaker, 1992) and consumer's willingness to pay premium prices (Keller, 1993; Anselmsson et al., 2007). Brand equity serves three important roles: (a) it acts as a magnet to attract new customers to the firm, (b) serves as a reminder to the customers about the organisation's products and services, (c) it is customer's emotional tie to the organisation (Lemon et al., 2001).

A number of empirical researches have been conducted to evaluate brand equity.

Copyright (C) 2011 Goi Chai Lee and Fayrene Chieng Yew Leh. This is an open access article distributed under the Creative Commons Attribution License unported 3.0, which permits unrestricted use, distribution, and reproduction in any medium, provided that original work is properly cited. Contact Author: Goi Chai Lee Emaill: goi.chai.lee@curtin.edu.my 
However, not much research has been done to apply brand equity concepts and measures to Malaysian brands. Thus, the objective of this research is to develop a valid and reliable model of Malaysian brand equity by assessing the dimensions of the brand equity constructs.

\section{Literature Review}

\section{Overview}

The reality that emerges from the various researches in brand equity through the years is that there is considerable debate regarding the definition of brand equity and its measurements (Yoo and Donthu, 2001). However, brand equity is accepted as the overall utility that customers place in a brand (De Chernatony and McDonald, 2003; Vazquez at el, 2002). The definitions of brand equity can be classified into two perspectives. The first perspective of brand equity is from a financial market's point of view where the asset value of a brand is appraised (Farquhar et al., 1991, Simon and Sullivan, 1993).

Recently, brand equity has increasingly been defined in customer-based contexts, which defines brand equity as the value of a brand to the customer (Aaker, 1991; Keller, 1993; Cobb-Walgren et al., 1995; van Osselaer and Alba, 2000). Aaker (1991) defines brand equity as "a set of brand assets and liabilities linked to a brand, its name and symbol that add to or subtract from the value provided by a product or service to a firm and/or to that firms' customers." Brand awareness, brand associations, perceived quality, brand loyalty and other proprietary assets were the five assets of brand equity. Keller (2003) argued that the power of a brand lies in the minds of the customers and what they have experienced and learned about the brand over time. He defines customer-based brand equity as "the differential effect that brand knowledge has on consumer response to the marketing of that brand". Brand knowledge consists of brand awareness and brand image.
Keller (2003) described customer-based brand equity as a multidimensional concept. Several empirical studies on the dimensions of customer-based brand equity (eg: CobbWalgren et al., 1995; Yoo and Donthu, 2001; Pappu et al., 2005; Washburn and Plank, 2002) are all derived from Aaker (1991) and Keller (1993) frameworks where brand equity can be measured by four constructs: brand awareness, brand association, perceived quality and brand loyalty.

Yoo and Donthu (2001) developed multidimensional scale for measuring customerbased brand equity. This scale was later validated by Washburn and Plank (2002). However, the dimensionality of the customer-based brand equity needs to be refined (Washburn and Plank, 2002; Pappu et al., 2005) as to improve the measurement of consumer-based brand equity.

In this study, customer-based brand equity is conceptualized in accordance to Aaker (1991, 1996) and Keller (1993)'s models. A description of the dimensions and their constructs on which brand equity is based is examined and tested in the succeeding sections of this study.

\section{Brand Awareness}

Brand awareness is a key determinant of brand equity (Aaker, 1996; Keller, 2003; Mackay, 2001; Yoo and Donthu, 2001; Washburn and Plank, 2002; Pappu et al., 2005). It is defined as an individual's ability to recall and recognize a brand (Aaker, 1996; Keller, 2003). Top-of-mind and brand dominance is other levels of awareness included by Aaker (1996) in measuring awareness. Awareness can affect customers' perceptions, which lead to different brand choice and even loyalty (Aaker, 1996). A brand with strong brand recall (unaided awareness) and top of mind can affect customers' perceptions, which lead to different customer choice inside a product category (Aaker, 1996; Kimpakorn and Tocquer, 2010). 


\section{Brand Associations}

Aaker (1996) conceptualizes brand awareness that must precede brand associations. That is where a consumer must first be aware of the brand in order to develop a set of associations (Washburn and Plank, 2002). Brand association contains the meaning of the brand for consumers (Keller, 1993). It is anything linked in memory to a brand (Aaker, 1991). Brand associations are mostly grouped into a product-related attribute like brand performance and nonproduct related attributes like brand personality and organizational associations (Aaker, 1996; Chen, 2001; Keller, 2003; Netemeyer et al., 2004; Pappu et al., 2005). Customers evaluate a product not merely by whether the product can perform the functions for which it is designed for but the reasons to buy this brand over the competitors (Aaker, 1996) such as brand's fault-free and long-lasting physical operation and flawlessness in the product's physical construction (Lassar et al., 1995).

Brand personalities include symbolic attributes (Aaker, 1996; Keller, 1993; Chen, 1996) which are the intangible features that meet consumers' needs for social approval, personal expression or self-esteem (Keller, 1993; Hankinson and Cowking, 1993; Pitta and Katsanis, 1995). The symbolic attributes that are commonly linked to a brand are:

1. Social Image: Lassar et al (1995) argue that social image which includes the attributions a consumer makes and a consumer thinks that others make to the typical user of the brand is more relevant in measuring customer-base brand equity.

2. Perceived value: Consumer choice of a brand depends on a perceived balance between the price of a product and all its utilities (Lassar et al., 1995). A consumer is willing to pay premium prices due to the higher brand equity (Aaker, 1993).
3. Trustworthiness: Trustworthiness refers to the level of confidence consumer places in the organisation (Lassar et al., 1995). As a customer buys a good or service before experiencing it, fostering of trust is a key to build a customer relationship (Kinard and Capella, 2006).

4. Country-of- origin: Country of origin leads to associations in the minds of consumers (Aaker, 1991; Keller, 1993). Country image can influence perceived quality and brand loyalty. (Pappu et al, 2007). Country of origin refers to the country of origin of a firm or a product (Johansson et al., 1985; Ozsomer and Cavusgil, 1991).

Organisational associations include corporate ability and social responsibility associations (Aaker, 1996; Chen, 2001). Consumers will consider the organisation, which is related to people, values, and programs that lies behind the brand. Brandas-organisation can be particularly helpful when brands are similar with respect to attributes or when a corporate brand is involved (Aaker, 1996). Corporate social responsibility (CSR) is influencing the development of brands (Blumenthal and Bergstrom, 2003) as the public is interested to know what, where, and how much brands are giving back to society.

\section{Perceived Quality}

Perceived quality is defined as the customer's judgment about a product's overall excellence or superiority in comparison to alternative's brand (Zeithaml, 1988; Aaker, 1996) and overall superiority that ultimately motivates the customer to purchase the product (Aaker and Jacobson, 1994). It is difficult for customers to make a rational judgment of the quality. They are likely using quality attributes like colour, flavour, form, appearance of the product and the availability of production information (Bernués et al., 2003) to 'infer' quality (Acebrón and Dópico, 2000). 


\section{Brand Loyalty}

Aaker (1991) defines brand loyalty as 'the attachment that a customer has to a brand'. Two different levels of loyalty are classified: behavioural and cognitive loyalty (Keller, 1998). Behavioural loyalty can be indicated by a number of repeated purchases (Keller, 1998) or commitment to rebuy the brand as a primary choice (Oliver, 1997, 1999). Cognitive loyalty refers to the consumers' intention to buy the brand as the first choice (Keller, 1998; Yoo and Donthu, 2001). Another indicator of loyalty is the customer's willingness to pay higher price for a brand in comparison with another brand offering similar benefits (Aaker, 1996; Chaudhuri and Holbrook, 2001; Srinivasan et al., 2002).

\section{Methodology}

\section{Research Design}

This questionnaire is divided into two parts. The first is concerned with the demographic.
The second part is thirty variables associated with the brand awareness, brand associations, perceived quality and brand loyalty. The data collection instrument is a structured questionnaire. A pool of 30 items compiled from the literature was incorporated in the questionnaire (Table 1). Four variables were included for brand awareness, seventeen variables for brand association, five for perceived quality and four for brand loyalty. A Likert-scale of 1 to 5 was adopted for all the brand equity measures with the anchors 'strongly disagree' (1) and 'strongly agree' (5). The items were developed with reference to the empirical studies of Yoo and Donthu (2001) and Lassar et al (1995). The reason for referring to their scale development studies is that their scales are the most commonly accepted measure of customer-based brand equity (Washburn and Plank, 2002). 
Table1: Dimensions of Brand Equity and its Constructs

\begin{tabular}{|c|c|c|}
\hline 1. & \multirow{4}{*}{ Brand Awareness (Aw) } & I have difficulty in imagining this brand in my mind. \\
\hline 2. & & I can recognise this brand among competing brands. \\
\hline 3. & & $\begin{array}{l}\text { This brand is the only brand recalled when I need to make a } \\
\text { purchase decision on the product. }\end{array}$ \\
\hline 4. & & $\begin{array}{l}\text { This brand comes up first in my mind when I need to make a } \\
\text { purchase decision on the product. }\end{array}$ \\
\hline 5. & \multirow{17}{*}{$\begin{array}{l}\text { Brand Associations } \\
\text { (BA) }\end{array}$} & The brand is made so as to work trouble free. \\
\hline 6. & & This brand is safe to use/consume. \\
\hline 7. & & During use, the brand is highly unlikely to be defective. \\
\hline 8. & & I can quickly recall the logo of this brand. \\
\hline 9. & & In its status and style, this brand matches my personality. \\
\hline 10. & & The brand is well regarded by my friends. \\
\hline 11. & & I am proud to own a product of this brand. \\
\hline 12. & & $\begin{array}{l}\text { I consider the company and people who stand behind the brand are } \\
\text { very trustworthy. }\end{array}$ \\
\hline 13. & & The brand is well priced. \\
\hline 14. & & $\begin{array}{l}\text { Considering what I pay for the brand, I get much more than my } \\
\text { money's worth. }\end{array}$ \\
\hline 15. & & $\begin{array}{l}\text { I can get the same benefits from this brand when compared to the } \\
\text { imported brand(s). }\end{array}$ \\
\hline 16. & & I buy/use this brand of product because it is a Malaysian brand. \\
\hline 17. & & $\begin{array}{l}\text { The brand's country of origin/manufacture is important in choosing } \\
\text { this product. }\end{array}$ \\
\hline 18. & & $\begin{array}{l}\text { I consider the company and people who stand behind the brand } \\
\text { have the expertise in producing the product. }\end{array}$ \\
\hline 19. & & $\begin{array}{l}\text { I believe that this company and people who stand behind the brand } \\
\text { are socially responsible. }\end{array}$ \\
\hline 20. & & I believe that this company does not take advantage of consumers. \\
\hline 21. & & I believe that this company is contributing to the society. \\
\hline 22. & \multirow{5}{*}{ Perceived Quality (PQ) } & This brand is of good quality. \\
\hline 23. & & I can expect superior performance from this brand. \\
\hline 24. & & This brand is very reliable. \\
\hline 25. & & $\begin{array}{l}\text { I don't have difficulties in finding the information that I need from } \\
\text { the label of the package. }\end{array}$ \\
\hline 26. & & $\begin{array}{l}\text { This brand is better as compared to other brand(s) of the product in } \\
\text { terms of the colour/flavour/form/ appearance. }\end{array}$ \\
\hline 27. & \multirow{4}{*}{ Brand Loyalty (BL) } & After using the brand, I grow fond of it. \\
\hline 28. & & I will definitely buy this brand of product again. \\
\hline 29. & & $\begin{array}{l}\text { I will definitely buy this brand of product although its price is higher } \\
\text { than the other brand(s) of the product that offer similar benefits. }\end{array}$ \\
\hline 30. & & I will not buy other brands, when this brand is available at the store. \\
\hline
\end{tabular}

\section{Data Collection}

500 questionnaires were sent to all parts of Malaysia, especially major cities like Kuching, Miri, the area around the Klang Valley, Kota Kinabalu, Johor Bahru. Respondents were randomly selected. However, only 489 valid samples were used for the analysis. Overall, six months was used to collect all the questionnaires. Malhotra (1999) suggested minimum sample of problem solving is at least 200 samples. Thus, we have used the 
recommendations of Malhotra (1999), which are at least 200 samples.

\section{Data Analysis}

For purposes of data analysis, SPSS was used to analyse the Cronbach's alpha, factor analysis and correlation.

\section{Findings and Analysis}

\section{Demographics}

The sample indicates a balance between males (51.7\%) and females (48.3\%). Majority of the respondents are those age $35(60 \%)$ and monthly income of RM3,001-RM5,000 (41\%). With respect to the regions respondents currently stay, majority is from Sabah and Sarawak (32.5\%) and followed by central region $(19.8 \%)$ and southern region $(19.2 \%)$. The breakdown of the study in terms of regions could be considered representative of the population of Malaysia since most of the regions are represented in the sample (Table 2).

Table 2: Demographics

\begin{tabular}{|c|c|c|}
\hline & Frequency & Percent \\
\hline \multicolumn{3}{|l|}{ Gender } \\
\hline Male & 253 & 51.7 \\
\hline Female & 236 & 48.3 \\
\hline Total & 489 & 100 \\
\hline \multicolumn{3}{|l|}{ Age } \\
\hline $18-25$ & 154 & 31.5 \\
\hline $26-35$ & 140 & 28.6 \\
\hline $36-45$ & 146 & 29.9 \\
\hline $46-55$ & 40 & 8.2 \\
\hline$>55$ & 9 & 1.8 \\
\hline Total & 489 & 100 \\
\hline \multicolumn{3}{|l|}{ Income(Monthly) } \\
\hline$<=$ RM1000 & 130 & 26.6 \\
\hline RM1001 - 3000 & 80 & 16.4 \\
\hline RM3001 - 5000 & 199 & 40.7 \\
\hline RM5001 - 7000 & 62 & 12.7 \\
\hline RM7001 - 10000 & 7 & 1.4 \\
\hline$>$ RM10000 & 11 & 2.2 \\
\hline Total & 489 & 100 \\
\hline \multicolumn{3}{|l|}{ Education } \\
\hline Secondary School & 90 & 18.4 \\
\hline Certificate/ Diploma & 104 & 21.3 \\
\hline Bachelor Degree & 263 & 53.8 \\
\hline Master Degree & 26 & 5.3 \\
\hline
\end{tabular}

\section{Reliability and Validity of the Constructs}

Internal reliability of the 30 construct scale was assessed using Cronbach's Alpha technique. The scale produced an alpha of 0.96 , which is highly acceptable for an attitude scale (Burns and Burns, 2008). The validity of the constructs is justified as the measures were developed based on a theoretical framework that was derived from extensive literature review. 


\section{Factor Analysis}

The 30 constructs were tested by principal components analysis, using varimax rotation. According to the four dimensions proposed by Aaker (1991) in the brand equity literature, we have chosen a four factor solution that reduced the 30 constructs to four factors (alpha=0.96), with eigenvalues greater than 1.0 except the brand awareness factor which has an eigenvalue less than one. These four factors explained 59\% per cent of the total variance.

By convention, the factor loadings should be at least 0.3 but for a variable to unambiguously represent a factor, the loading should be 0.6 and above (Burns and
Burns, 2008). In this study, the brand equity constructs with a loading below 0.6 were excluded from further analysis. 14 constructs remained in this study. Table 3 lists the factors in the order in which they were extracted from the data.

With reference to the rotation, Factor 1 is loaded on 3 constructs that reflects perceived quality of Malaysian brand and accounted for $47 \%$ of the variance. Factor 2 is loaded with 5 constructs and accounts for $5 \%$ of the variance. Factor 2 is labeled as brand associations. The third factor accounted for $3 \%$ of the variance and is loaded on 3 constructs suggesting it is measuring brand loyalty. The last factor, measuring brand awareness, is accounted for $3 \%$ of the variance and loaded with 3 constructs.

Table 3: Result for Factor Analysis, Factors Variance, Loadings and Brand Equity Constructs

\begin{tabular}{|c|c|c|c|}
\hline Factor & $\begin{array}{l}\text { Factor Interpretation } \\
\text { (\% of variance } \\
\text { explained) }\end{array}$ & Brand equity constructs & Loading \\
\hline \multirow{3}{*}{$\mathrm{F} 1$} & \multirow{3}{*}{$\begin{array}{l}\text { Perceived Quality } \\
(47 \%)\end{array}$} & This brand is very reliable (PQ1) & 0.679 \\
\hline & & This brand is safe to use/consume.(PQ2) & 0.679 \\
\hline & & This brand is of good quality. (PQ3) & 0.648 \\
\hline \multirow{5}{*}{$\mathrm{F} 2$} & \multirow{5}{*}{$\begin{array}{l}\text { Brand Associations } \\
(5 \%)\end{array}$} & $\begin{array}{l}\text { I consider the company and people who stand } \\
\text { behind the brand have the expertise in producing } \\
\text { the product. (As1) }\end{array}$ & 0.701 \\
\hline & & $\begin{array}{l}\text { I believe that this company and people who stand } \\
\text { behind the brand are socially responsible. (As2) }\end{array}$ & 0.694 \\
\hline & & $\begin{array}{l}\text { I believe that this company does not take } \\
\text { advantage of consumers. (As3) }\end{array}$ & 0.663 \\
\hline & & The brand is well priced. (As4) & 0.645 \\
\hline & & $\begin{array}{l}\text { I believe that this company is contributing to the } \\
\text { society. (As5) }\end{array}$ & 0.643 \\
\hline \multirow{3}{*}{ F3 } & \multirow{3}{*}{ Brand Loyalty (3\%) } & $\begin{array}{l}\text { I will not buy other brands, when this brand is } \\
\text { available at the store. (L1) }\end{array}$ & 0.702 \\
\hline & & $\begin{array}{l}\text { I will definitely buy this brand of product although } \\
\text { its price is higher than the other brand(s) of the } \\
\text { product that offer similar benefits. (L2) }\end{array}$ & 0.699 \\
\hline & & $\begin{array}{l}\text { I buy/use this brand of product because it is a } \\
\text { Malaysian brand. (As8) }\end{array}$ & 0.693 \\
\hline \multirow{3}{*}{ F4 } & \multirow{3}{*}{ Brand Awareness (3\%) } & $\begin{array}{l}\text { I have difficulty in imagining this brand in my } \\
\text { mind. (Aw1) }\end{array}$ & 0.733 \\
\hline & & $\begin{array}{l}\text { I can recognise this brand among competing } \\
\text { brands.(Aw2) }\end{array}$ & 0.711 \\
\hline & & $\begin{array}{l}\text { This brand comes up first in my mind when I need } \\
\text { to make a purchase decision on the product. (Aw3) }\end{array}$ & 0.517 \\
\hline
\end{tabular}




\section{Conclusion and Future Research}

This study focuses on four dimensions of brand equity, which are perceived quality, brand associations, brand loyalty and brand awareness and its measurements. Conceptualizing brand equity from the consumer's perspective is useful because it suggests both specific guidelines for marketing strategies and tactics and areas where research can be useful in assisting managerial decision making. Two important points emerge from this conceptualization. First, marketers should take a broad view of marketing activity for a brand and recognize the various effects it has on brand knowledge, as well as how changes in brand knowledge affect more traditional outcome measures such as sales. Second, markets must realize that the long-term success of all future marketing programs for a brand is greatly affected by the knowledge about the brand in memory that has been established by the firm's short-term marketing efforts. In short, because the content and structure of memory for the brand will influence the effectiveness of future brand strategies, it is critical that managers understand how their marketing programs affect consumer learning and thus subsequent recall for brand-related information (Keller, 1993).

Derived from the analysis, this model includes four factors and 14 variables. For further study in the future, we will investigate the fitness model by using the structure equation model (SEM). Continuation of this study, the problems will be studied in the future is whether the brand awareness, brand associations, perceived quality and brand loyalty has a positive impact on brand equity.

\section{References}

Aaker, D. A. (1991). Managing Brand Equity, Free Press, New York.
Aaker, D. A. (1996). "Measuring Brand Equity Across Products and Markets," California Management Review, 38 (3). 102-120.

Aaker, D. A. \& Jacobson, R. (1994). "Study Shows Brand-Building Pays off for Stockholders," Advertising Age 65 (30). 18.

Acebrón, L. B \& Dópico, D. C. (2000). “The Importance of Intrinsic and Extrinsic Cues to Expected and Experienced Quality: An Empirical Application for Beef," Food Quality and Preference 11(3). 229-238.

Anselmsson, J., Johansson, U. \& Persson, N. (2007). "Understanding Price Premium for Grocery Products: A Conceptual Model of Customer-based Brand Equity," Journal of Product \& Brand Management, 16 (6). 401414.

Bernués, A., Olaizola, A. \& Corcoran, K. (2003). "Extrinsic Attributes of Red Meat as Indicators of Quality in Europe: An Application for Market Segmentation," Food Quality and Preference, 14 (4). 265-276.

Bharadwaj, S. G., Varadarajan, P. R. \& Fahy, J. (1993). "Sustainable Competitive Advantage in Service Industries: A Conceptual Model and Research Propositions," Journal of Marketing, 57 (4). 83-99.

Burns, R. B. \& Burns, R. A. (2008). Business Research Methods and Statistics using SPSS, Sage Publications Ltd., London.

Chaudhuri, A. \& Holbrook, M. B. (2001). “The Chain of Effects from Brand Trust and Brand Effect to Brand Performance: The Role of Brand Loyalty," Journal of Marketing 65 (2). 81-93.

Chen, A. C. H. (1996). 'The Measurement and Building of Customer-based Brand Equity,' PhD dissertation, National Chengchi University, Taiwan. 
Chen, A. C.-H. (2001). "Using Free Association to Examine the Relationship between the Characteristics of Brand Associations and Brand Equity," Journal of Product \& Brand Management, 10 (7). 439-451.

Cobb-Walgren, C. J., Ruble C. A. \& Donthu, N. (1995). "Brand Equity, Brand Preference, and Purchase Intent," Journal of Advertising, 24 (3). 25-40.

De Chernatony, L \& McDonald, M. (2003). Creating Powerful Brands, 3rd Ed., Butterworth-Heinemann, Oxford.

Farquhar, P. H. (1989). 'Managing Brand Equity,' Marketing Research, 1 (3). 24-33.

Farquhar, P. H., Han, J. Y. \& Ijiri, Y. (1991). "Recognizing and Measuring Brand Assets," Marketing Science Institute, Cambridge, MA.

Farquhar, P. H. \& Herr, P. M. (1993). "The Dual Structure of Brand Associations," Brand Equity \& Advertising: Advertising's Role in Building Strong Brands, Aaker, DA and Biel, A. (eds). Erlbaum, Hillsdale, NJ.

Hankinson, G. \& Cowking, P. (1995). 'What Do You Really Mean by the Brand?,' The Journal of Brand Management 3 (1). 43-50.

Johansson, J. K., Douglas, S. P. \& Nonaka, I. (1985). "Assessing the Impact of Country of Origin on Product Evaluations: A New Methodological Perspective," Journal of Marketing Research, 5 (3). 175-187.

Keller, K. L. (1993). “Conceptualizing, Measuring, and Managing Customer-based Brand Equity," Journal of Marketing, 57 (1). 1-22.

Keller, K. L. (2003). Strategic Brand Management, 2nd ed., Prentice Hall, Upper Saddle River, NJ.

Keller, K. L. \& Aaker, D. A. (1992). "The Effects of Sequential Introductions on Brand Extensions," Journal of Marketing Research 29 (1). 35-50.
Kimpakorn, N. \& Tocquer, G. (2010). "Service Brand Equity and Employee Brand Commitment," Journal of Services Marketing 24 (5). 378-388.

Kinard, B. R. \& Capella, M. L. (2006). "Relationship Marketing: The Influence of Consumer Involvement on Perceived Service Benefits," Journal of Services Marketing 20 (6). 359-368.

Lassar, W., Mittal, B. \& Sharma, A. (1995). "Measuring Customer-Based Brand Equity," Journal of Consumer Marketing, 12 (4). 11-19.

Lemon, K. N., Rust, R. T. \& Zeithaml, V. A. (2001). "What Drives Customer Equity?," Marketing Management, 10 (1). 20-25.

Mackay, M. M. (2001). "Evaluation of Brand Equity Measures: Further Empirical Results," The Journal of Product and Brand Management, 10 (1). 38-51.

Malhotra, N. K. (1999). 'Marketing Research: An Applied Orientation,' International Edition, Prentice Hall, New Jersey.

Netemeyer, R. G., Krishnan, B., Pullig, C., Wang, G., Yagci, M., Dean, D., Ricks, J. \& Wirth, F. (2004). "Developing and Validating Measures of Facets of Customer-based Brand Equity," Journal of Business Research, 57 (2). 209-224.

Ozsomer, A. \& Cavusgil, S. T. (1991). 'Country of Origin Effects on Product Evaluations: A Sequel to Bilkey and Nes Review,' Gilly, M., Dwyer, TF., Leigh, TW., Dubinsky, AJ., Richins, ML., Curry, D., Venkatesh, A., Kotabe, M., Dholakia, RR. and Hills, GE. (eds). American Marketing Association, Chicago, IL.

Pappu, R., Quester, P. G. \& Cooksey, R. W. (2005). "Consumer-based Brand Equity: Improving the Measurement - Empirical Evidence," Journal of Product and Brand Management, 14 (3). 143-154.

Pappu, R., Quester, P. G. \& Cooksey, R. W. (2007). "Country Image and Consumer-based 
Brand Equity: Relationships and Implications for International Marketing," Journal of International Business Studies, 38 (5). 726745.

Pitta, D. A. \& Katsanis, L. P. (1995). "Understanding Brand Equity for Successful Brand Extension," Journal of Consumer Marketing, 12 (4). 51-64.

Simon, C. J. \& Sullivan, M. W. (1993). “The Measurement and Determinants of Brand Equity: A Financial Approach," Marketing Science, 12 (1). 28-53.

Srinivasan, S. S., Anderson, R. \& Ponnavolu, K. (2002). "Customer Loyalty in E-Commerce: An Exploration of Its Antecedents and Consequences," Journal of Retailing, 78 (1). 41-50.

Srivastava, R. K. \& Shocker A. D. (1991). 'Brand Equity: A Perspective on its Meaning and Measurement,' Marketing Science Institute, Cambridge Mass.

Sya, L. S. (2004). "Malaysia Inviting," Brand Channel [Online], [Retrieved March 22, 2011],

http://www.brandchannel.com/features_pro file.asp?pr_id=200.

Van Osselaer, S. M. J. \& Alba J. W. (2000). "Consumer Learning and Brand Equity," Journal of Consumer Research, 27 (1). 1-16.

Vázquez R., Río A. B. D. \& Iglesias, V. (2002). "Consumer-based Brand Equity: Development and Validation of a Measurement Instrument," Journal of Marketing Management, 18(1-2). 27-48.

Washburn, J. H. \& Plank, R. E. (2002). "Measuring Brand Equity: An Evaluation of a Consumer-based Brand Equity Scale," Journal of Marketing Theory and Practice, 10 (1). 4662.

Wood, L. (2000). "Brands and Brand Equity: Definition and Management," Journal of Management Decision, 38 (9). 662-669.
Yoo, B. \& Donthu, N. (2001). "Developing and Validating a Multidimensional Consumerbased Brand Equity Scale," Journal of Business Research, 52 (1). 1-14.

Zeithaml, V. A. (1988). "Consumer Perceptions of Price, Quality, and Value: A Means-end Model and Synthesis of Evidence," Journal of Marketing, 52 (3). 2-22. 